Summer 2013

\title{
Occupy the System! Societal Constitutionalism and Transnational Corporate Accounting
}

\author{
Moritz Renner \\ University of Bremen, moritz.renner@uni-bremen.de
}

Follow this and additional works at: https://www.repository.law.indiana.edu/ijgls

Part of the Constitutional Law Commons, International Law Commons, and the Law and Society Commons

\section{Recommended Citation}

Renner, Moritz (2013) "Occupy the System! Societal Constitutionalism and Transnational Corporate Accounting," Indiana Journal of Global Legal Studies: Vol. 20 : Iss. 2 , Article 13.

Available at: https://www.repository.law.indiana.edu/ijgls/vol20/iss2/13

This Symposium is brought to you for free and open access by the Law School Journals at Digital Repository @ Maurer Law. It has been accepted for inclusion in Indiana Journal of Global Legal Studies by an authorized editor of Digital Repository @ Maurer Law. For more information, please contact rvaughan@indiana.edu.

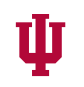

JEROME HALL LAW LIBRARY

INDIANA UNIVERSITY

Maurer School of Law
Bloomington 


\title{
Occupy the System! Societal Constitutionalism and Transnational Corporate Accounting
}

\author{
MORITZ RENNER*
}

\begin{abstract}
Today's most pressing constitutional question is posed by a global economic system whose expansive tendencies seem no longer controllable. In addressing this question, the theory of Societal Constitutionalism apparently shifts established ideological coordinates by developing a theory of the self-constitutionalization of social spheres. It seeks to combine the virtues of grassroots democracy with the sophistication of systemic social theory. Thus, its normative claim can be formulated as an oxymoron: "Occupy the System!" The claim is an oxymoron because it points to the apparent impossibility of critical social theory in a functionally differentiated society: How can a functional system such as the economy be "occupied" or "democratized"? Yet the oxymoron contains a grain of truth. With a view to the concrete example of transnational standard-setting procedures in the field of corporate accounting, this article examines institutional and systemic processes that enable an emerging political discourse at the core of the global economic system.
\end{abstract}

\section{The Constitutional QUeSTion of LATE MODERnity}

Whereas the central constitutional question of the eighteenth and nineteenth century has been the taming of the political leviathan, constitutional theory in the twentieth century has had a different-if sometimes implicit-agenda: the control of economic power. Ever since Georg Friedrich Hegel's lucid analysis of the emergence of bourgeois society, ${ }^{1}$ social theory has struggled with the challenge of an

\footnotetext{
* Lichtenberg Professor of Transnational Commercial Law and Legal Theory, University of Bremen (Germany).

1. Georg Friedrich Wilhelm Hegel \& Georg Lasson, Grundlinien der PHmosophie DES RECHTS [BASE LINES OF PHILOSOPHY OF LAW] §§ 183, 257 (Felix Meiner Verlag 1911) (1821) (Ger.).
}

Indiana Journal of Global Legal Studies Vol. 20, Issue 2 (2013)

(C) Indiana University Maurer School of Law 
increasingly self-referential economic system. Economic modernization allowed for individual emancipation from the close-knit social fabric of premodern times, but at the same time-and even more so with the rise of corporate capitalism ${ }^{2}$ - threatened the very possibility of collective political self-determination. Social and political movements throughout the last century have sought to overcome this dialectical tension, often by violent means. ${ }^{3}$ From today's perspective, the golden age of the welfare state in the second half of the twentieth century seems no more than a short respite from the continuing struggle, while economic globalization has begun to move the conflict to another arena.

The current financial crisis poses the constitutional question of late modernity anew: the question of how to contain the overexpansive tendencies of an economic system ever more disembedded from its societal context. ${ }^{4}$ The answers to this new-old constitutional question range from the austerity-oriented approaches followed by the governments of Germany and other Northern European countries in the context of Eurozone negotiations to the anarchist ideas of the "Occupy Now!" movement. As different as these answers may seem at first sight, they can be clearly situated in an ideological coordinate system that has basically remained unchanged since the 1920s (Part II). The constitutional form of the modern nation-state has for some decades rendered the ideological-and conflictual-nature of political economy almost invisible. Now, it is brought to plain light by contemporary processes of transnationalization (Part III). The transnational arena not only calls for, but also allows for fresh answers to the constitutional question of late modernity; one of these answers might be offered by the project of Societal Constitutionalism (Part IV). The project of Societal Constitutionalism merges existing and seemingly contradictory theories of political economy into a normative claim, which can be formulated as "Occupy the System!" The claim, however, is an oxymoron: you can occupy a bank, but you cannot occupy the financial system. The theory of Societal Constitutionalism is based on this oxymoronic claim. Starting from systems theory's insight that the functional

2. See Adolf A. Berle, Jr. \& Gardiner C. MEANS, The Modern Corporation AND PRIVATE PROPERTY 357 (Macmillan 1948) (1932) ("The rise of the modern corporation has brought a concentration of economic power which can compete on equal terms with the modern state-economic power versus political power, each strong in its own field. ... The future may see the economic organism, now typified by the corporation, not on an equal plane with the state, but even superseding it as the dominant form of social organization.").

3. See Gunther Teubner, Constitutional Fragments: Societal Constitutionalism IN GLOBALIZATION 21-23 (2012) (on "totalitarian societal constitutionalim").

4. See generally KARL POLANYI, THE GREAT TRANSFORMATION (1944) (regarding the notion of "disembeddedness"). 
differentiation of economy, politics, and law is irreversible, the theory nevertheless tries to define the conditions for a mutual irritation and interaction of those social systems. This paper, while considering with a view to the example of transnational standard setting in corporate financial reporting (Part V), tries to apply the paradoxical claim of Societal Constitutionalism to the newly emerging transnational institutions in the global economic system (Part VI).

\section{IDEOLOGICAL ROOTS: ECONOMIC DEMOCRACY VERSUS ECONOMIC CONSTITUTIONALISM}

In the first half of the twentieth century, two different traditions have laid the groundwork for contemporary discussions of political economy. The German debate of the Weimar Republic has labeled these approaches as Economic Democracy (Wirtschaftsdemokratie) on the one hand and Economic Constitutionalism (Wirtschaftsverfassung) on the other. Searching for a "third way" between laissez-faire liberalism on the one hand, and socialist planned economies on the other, they both explicitly frame the problem of economic power in-albeit different-constitutional terms.

The ideas of Economic Democracy were developed by socialist and social democratic thinkers. As the head of a trade union supported research group, economist Fritz Naphtali elaborated his influential theory of Wirtschaftsdemokratie in 1928,5 explicitly referring to earlier concepts of "Industrial Democracy" developed in Great Britain. 6 Naphtali defines two central tenets of Economic Democracy. On the one hand, he sees Economic Democracy as based on a "critique of the shortcomings of political democracy"; on the other hand, he conceives its goal as "a form of economic constitution, a democratic constitution of the economy as opposed to economic autocracy." " To reach this goal, he demands a "democratization of the economy," that is, "the abolishment of all authority and the transformation of the leading organs of the economy from organs of capitalist interest into those of the common interest."8

Translating this demand into concrete policy objectives, however, Naphtali opts for a rather modest strategy of opening the economic process to inputs from political discourse through specific legal and

5. FRITZ NAPHTALI, WIRTSCHAFTSDEMOKRATIE. IHR WESEN, WEG UND ZIEL (Europäische Verlagsanstalt 4 ed. 1977 [1928]).

6. See generally SidNEY WebB \& BeATRICE WEBb, INDUSTRIAL DEMOCRACY (1926 ed.)

(1897) (describing trade unions and collective bargaining).

7. NAPHTALI, supra note 5, at 29.

8. Id. at 30 . 
organizational institutions: employment law, workers' councils within corporations, representation of workers in political institutions, political control of monopolies, and the promotion of consumers' associations. ${ }^{9}$ Naphtali thus relies on both the democratic parliamentary institutions of the nation-state and democratic bodies within corporations and other private bodies.

In the United States, similar ideas were developed by one of the leading corporate lawyers of his time, Adolf A. Berle. In his 1959 book Power Without Property, Berle recapitulates his earlier ideas about economic power and at the same time tries to develop an adequate theory of legitimacy, reflecting the "reality of economic democracy."10 For Berle, the main source of legitimacy for economic power is public consensus. By posing a hypothetical situation of what would transpire if "a well-known gangster were by some accident to be duly elected a director and duly chosen President of the United States Steel Corporation," he explains that, even in economic contexts, formal legal procedures are seldom sufficient to generate legitimacy. ${ }^{11}$ However, to assess legitimacy, he goes on to explain that "conventional stereotypes of 'democratic procedure' are not particularly helpful."12 "Public consensus," he observes, is usually not the consensus of a general public or even within a parliamentary legislature, but rather refers to the common persuasion of a certain community, often dominated by "the conclusions of careful university professors, the reasoned opinions of specialists, the statements of responsible journalists, and at times the solid pronouncements of respected politicians." 13 Different approaches in Economic Democracy, while agreeing on the goal of opening the economy to political discourse, thus expose widely divergent views on what they define as political discourse.

In theories of Economic Constitutionalism, in contrast, which emerged roughly at the same time, the concept of the political is hardly defined at all. Their main contribution to the debate, however, lies in their highlighting of the role of law in the interaction of economy and politics. Economic Constitutionalism has its roots in ordoliberal thought, which conceives the economy as a self-regulating system that cannot be politicized without sacrificing the basic principles of economic freedom. At the same time, ordoliberal thought acknowledges both the self-destructive tendencies of the economic system arising out of the

9. Id. at 148-64 (on employment law), 172-74 (on workers' councils), 35-51 (on control of monopolies), 93-108 (on consumers' associations).

10. Adolf A. Berle, JR., POWER Without Property 110-16 (1959).

11. Id. at 109 .

12. Id, at 108 .

13. Id. at 113 . 
concentration of private power and the harmful effects of the market mechanism on other social spheres. Therefore, a (constitutional) legal framework should contain the functional rationality of the economic system by laying down the economic "rules of the game."14

Franz Böhm, one of the early masterminds of the ordoliberal school, develops this line of thought in his theory of a private law society. ${ }^{15}$ Only a market society under the rule of law and autonomous from the domain of political power, he argues, can protect the freedom of its citizens. ${ }^{16}$ With this approach, Böhm attacks the dominant corporatist zeitgeist by claiming that trusts and monopolies constitute a form of "private power and private coercion" that has to be controlled by law. ${ }^{17}$ The accumulation of economic power is considered a problem not only for the economic system but for society as a whole, specifically with a view to potential spillover effects in the political system. ${ }^{18}$ Economic power is identified as a threat to "social justice and civil liberties,"19 as concerning not only the realm of private law but also the very idea of democratic citizenship. ${ }^{20}$ On this basis, early ordoliberals argued that significant aspects of society, such as the education of its citizens, ${ }^{21}$ should be expressly exempted from the market mechanism, acknowledging that "the sober world of pure business draws from moral resources that are essential and more important than any principle of economics. Market, competition and the interplay of supply and demand do not create but only consume such reserves and must obtain them from spheres beyond the market." 22

As a consequence, the role of law is seen as both preserving and limiting the autonomy of the economic system in its relation to other

14. Franz Böhm, Die Ordnung Der Wirtschaft als geschichtLiche AufGabe UND RECHTSSCHÖPFERISCHE LEISTUNG 139 (1937).

15. Franz Böhm, Privatrechtsgesellschaft und Marktwirtschaft [Private Law Society and Market Economy], 17 ORDO 75 (1966) (Ger.).

16. Id. at 78 .

17. Franz Böhm, Das Problem der privaten Macht [The Problem with Power], 3 DIE JUSTIZ 324 (1928) (Ger.).

18. See Franz Böhm, Demokratie und ökonomische Macht [Democracy and Economic Power], in KARTELLE UND MONOPOLE IM MODERNEN RECHT [CARTELS AND MONOPOLIES IN MODERN LAW] 1, 8 (Institut für ausländisches und internationales Wirtschaftsrecht an der Johann-Wolfgang-Goethe-Universität Frankfurt am Main ed. 1960); see also Böhm, supra note 15 , at 121 .

19. Böhm, supra note 18 , at 8 (author's translation).

20. See id. at 21.

21. See Böhm, supra note 15 , at 102.

22. Wilhelm Röpke, Ethik und Wirtschaftsleben [Ethics and Economic Life], in WIRTSCHAFTSETHIK HEUTE: DREI REDEN AN JEDEN, DER PRODUZIERT, KAUFT UND VERKAUFT [Business Ethics Today: Three Speeches to Anyone Who Produces, Buys, and Sells] 24 (Wilhelm Röpke, et al. eds.,1956) (Ger.). 
functional systems of society. Specifically, the legal system shall mediate between the economic and the political system: "[c]onflicts between economy and politics are solved according to the principle of functional differentiation and formulated as questions of law." 23

The ordoliberal concept of Economic Constitutionalism obviously has close ties to approaches in social theory, which, based on Luhmannian systems theory, describe modern societies as fragmented into self-referential systems following different and incommensurable functional rationalities. Very much like the ordoliberals, Niklas Luhmann describes the economic system as no longer controllable by political interventions, ${ }^{24}$ and-at the same time-stresses the limitations of economic rationality and the "progressive 'arthrosis of the invisible hand." 25 Yet, while ordoliberals put their hopes in a legal "framework order" for the economy, Luhmann does not share such beliefs: ${ }^{26}$ "There is no way back to paradise." 27 The more optimistic ideas of Economic Democracy, in contrast, have been taken up by the Habermasian strand of Critical Theory, which calls for a reconciliation of the individual autonomy of the economic subject with the collective self-determination of the political community. ${ }^{28}$

\section{BetweEn Constitutional STATE AND NEW Constitutionalism}

In the historical reality of the Western European states after World War II, the ideas of ordoliberal Economic Constitutionalism have had an especially considerable impact. The legal and political framework of the newly born European Economic Community was expressly conceived as the economic constitution of the European internal market. ${ }^{29}$ The constitutional rules of a Rechtsgemeinschaft held both economic and

23. Peter Behrens, Weltwirtschaftsverfassung [World Economic Constitution], in JAHRBUCH FÜR NEUE POLITISCHE ÖKONOMIE 5, 8 (Karl-Ernst Schenk et al. eds., 2000) (Moritz Renner, trans.) (Ger.); see also Ernst-Joachim Mestmäcker, Macht-Recht-Wirtschaftsverfassung [Power-Law-Economic Constitution], 173 ZEITSCHRIFT FÜR DAS GESAMTE HANDELS- UND WIRTSCHAFTSRECHT 97 (1973) (GER.).

24. NikLas LuHManN, Die Wirtschaft der Gesellschaft [The Economy of Civil SOCIETY] 103 (1988) (Ger.).

25. Id. at 100 .

26. Id. at 104 n. 26.

27. Id. at 344 .

28. See Jürgen Habermas, Between FACTS AND Norms. Contributions to a DisCOURSE THEORY OF LAW AND DEMOCRACY 445 (1996).

29. See generally WERNER MUSSLER, DIE WIRTSCHAFTSVERFASSUNG DER EUROPÄISCHEN GEMEINSCHAFT IM WANDEL [THE ECONOMIC CONSTTTUTION OF THE EUROPEAN COMMUNTTY IN TRANSITION] (1998) (Ger.). 
political power at bay ${ }^{30}$ by focusing on market freedoms and competition law. ${ }^{31}$ At the same time, the ideas of Economic Democracy were largely marginalized and dismissed as socialist utopias. ${ }^{32}$ Only during a brief period in the heyday of the welfare state did concepts such as workers' codetermination gain a certain political support and, in Germany, were transposed into legal rules on the "corporate constitution" (Unternehmensverfassung). ${ }^{33}$ In this time period, the European welfare state presented itself as a fusion of ordoliberal Economic Constitutionalism and social democratic Economic Democracy, a "historical compromise"34_however, on a strong neocorporatist note.

The U.S. debate, meanwhile, was hardly irritated by these constitutionalist conceptions of the economy. Here, Keynesianism and Chicago School neoliberalism, as the two dominant economic paradigms, not only took their turns with changing governmental policies, but gradually dissolved into a peculiar amalgamate. ${ }^{35}$ Despite their apparent differences, these approaches erode rather than stabilize the boundary between economy and politics-and thus avoid any kind of constitutional terminology. While Keynesianism makes the case for direct, politically induced interventions in the market, the Chicago School, in contrast, seeks to subject even the state and the political process to the functional imperatives of the economic system. ${ }^{36}$

On both sides of the Atlantic, however, political economy was long considered a domestic affair. Both the European model of the welfare state and U.S. Keynesianism (which has been widely adopted by European policy makers since the 1960s) presuppose the centralized institutions of the nation-state are able to stabilize and intervene in the economic process. It was only the pure theory of Chicago School neoliberalism that seemed to allow for a model of political economy outside the nation-state, conceiving the economy as a globalized system beyond the reach of domestic politics. This simplified model obscured

30. See generally WALTER HALLSTEIN, DiE EUROPÄISCHE GEMEINSCHAFT [THE EUROPEAN COMMUNITY] (1973) (Ger.).

31. See Christian Joerges, What is Left of the European Economic Constitution? A Melancholic Eulogy, 30 EUR. L. REV. 461 (2005).

32. See Franz Böhm, Die Bedeutung der Wirtschaftsordnung für die politische Verfassung, SÜDDEUTSCHE JURISTENZEITUNG 141 (1946) (Ger.).

33. See Mitbestimmung im Unternehmen. Bericht der Sachverständigenkommission zur Auswertung der bisherigen Erfahrungen mit der Mitbestimmung, BT-Drucksache VI/334, 1970 [report of a high-level expert commission instituted by the German Parliament].

34. Christian Joerges, Working Through 'Bitter Experiences' Towards a Purified European Identity?, in LAW, DEMOCRACY AND SOLIDARITY IN A POST-NATIONAL UNION 175, 183 (Erik Oddvar Eriksen, et al. eds., 2008).

35. See Colin Crouch, The Strange Non-Death of Neoliberalism 97-124 (2011).

36. See Michel Foucault, NAISSANCE DE LA Biopolitique: COURS AU Collìge DE FRANCE (1978-1979) 222-239 (2004) (Fr.). 
the highly political nature of economic globalization for a long time by depicting it as a quasi-natural phenomenon. ${ }^{37}$

Interestingly, however, the neoliberal project itself reverted to constitutional terminology when it came to justifying the effects of economic globalization against growing political protest. Now, the so-called New Constitutionalism embodied by the global institutions of the World Bank, the World Trade Organization, the International Monetary Fund, and the International Investment regime entered the stage. ${ }^{38}$ At this point, in the late 1990s, all sides of the ideological spectrum began to (once again) discuss questions of global political economy in constitutional terms. Neoliberals employed constitutional rhetoric to reject the regulatory claims of nation-state governments in the framework of the international free trade regime, while social democratic politicians, trade unions, and the so-called antiglobalization movement vociferously defended the economic constitutions of the national welfare states. ${ }^{39}$ After the first stages of the current financial and debt crisis, European Union (EU) member states, led by Germany and France, have joined the antiglobalization movement by defending their ordoliberal economic constitution against "the financial markets." At the same time, new social movements such as the "Occupy Now!" movement, much in the spirit of earlier Economic Democracy approaches, demand a democratization of the economic sphere.

\section{The Project of Societal Constitutionalism}

It is the historical and ideological framework depicted above in which Gunther Teubner's project of Societal Constitutionalism finds its place. Teubner, however, expressly rejects the approaches of both Economic Democracy and Economic Constitutionalism. ${ }^{40} \mathrm{He}$ does so for two distinct but closely related reasons. On the one hand, he argues that approaches such as Economic Democracy, which aim at a politicization of social sectors beyond the political system, do not sufficiently respect the particular rationalities of the social sectors concerned, but try to transpose a model of the political process which is bound to fail outside the institutions of the nation-state. ${ }^{41}$ On the other hand, he criticizes the model of Economic Constitutionalism for universalizing the

37. See id. at 52-79.

38. See, e.g., David Schneidermann, Investment Rules and the New Constitutionalism, 25 LAW \& SOC. INQUIRY 757 (2000).

39. $C f$. Jürgen Habermas, Die postnationale Konstellation. Politische Essays 117.122 (1998). (Ger.)

40. See TEUBNER, supra note 3 , at $26-33$.

41. Id. at 26-29. 
rationality of the economic system and applying it to any other social sphere. ${ }^{42}$ Thus, it is the imperialism of both politics and economy against which Societal Constitutionalism seeks to position itself.

It seems questionable whether Teubner's critique is based on an adequate reconstruction of existing approaches in Economic Democracy and Economic Constitutionalism. Specifically, he reads ordoliberal theory as a mere continuation of the classical economic tradition without recognizing its aim of limiting economic power as a genuinely sociopolitical agenda. ${ }^{43}$ But the argument Teubner develops from here nonetheless offers a promising conceptual framework for analyzing the constitutional questions raised by a globalized economy. The strength in Teubner's approach is that he sees the ideas of Economic Democracy and Economic Constitutionalism not as mutually exclusive, but as complementary. On the one hand, he shares with Economic Democracy the aim of politicizing social spheres, such as the economy. ${ }^{44}$ On the other hand, he shares with Economic Constitutionalism the aim of identifying higher-level norms which both constitute and limit society's functional subsystems-including, but not restricted to, the political system. ${ }^{45}$ The normative agenda of Societal Constitutionalism thus takes on the somewhat paradoxical form of "Occupy the System!" and the boundaries of functional rationalities are at the same time reflected and subverted. 46

In pursuing this agenda, however, Teubner situates his starting point much closer to traditional approaches in Economic Constitutionalism than he seems willing to admit. In fact, the concept of the economic constitution as developed by early ordoliberal thinkers, such as Böhm, never called for an expansion of economic rationality to the whole of society, but rather for a containment of both the economic and the political system by law. ${ }^{47}$ The tendency of such approaches to

42. Id. at $30-34$.

43. The claim that "ordoliberal theory transforms the economic constitution into the constitution for the whole society" (id. at 30 ) and "is blind to economic expansionist tendencies" (id. at 31) is certainly not accurate for German ordo-liberalism in the tradition of Eucken, Böhm and Röpke. Admittedly, later exponents of the theory, starting with Hayek, have merged into neoclassical mainstream on this ambivalent heritage. Compare, for example, PHILIP MANOW, Ordoliberalismus als ökonomische Ordnungstheologie, 29 LEVIATHAN 179 (2001) (Ger.).

44. See TEUBNER, supra note 3 , at 114-23.

45. Id. at 75-88.

46. GUNTHER TEUBNER, Self-subversive Justice: Contingency or Transcendence Formula of Law?, 72 MOD. L. REv. 1 (2009).

47. Cf. Mestmäcker, supra note 23, at 104. 
embrace expertocratic or authoritarian structures, however, has rightly been criticized by scholars like Christian Joerges. ${ }^{48}$

It is therefore the attempt to introduce elements of Economic Democracy that is both crucial and very promising in Teubner's approach. Ordoliberal approaches to Economic Constitutionalism, which call for a containment of both economic and political power by the rule of law, have indeed often proven unsatisfactory if not dangerous, replacing economic and political power structures by no less powerful nonmajoritarian institutions. Here, Economic Democracy's promise of abolishing authoritarian institutions in both the economic and the political system and instead coupling both systems through processes of democratic deliberation unfolds its critical potential.

Yet at this point, Teubner's theory takes another turn that distances itself from its historical precursors in a rather forced way. Teubner criticizes approaches in Economic Democracy for their supposed fixation on the nation-state's political constitution. ${ }^{49}$ At the same time, he reduces the political system to "institutionalized politics"-and then elaborates on a conceptual distinction between "la politique" and "le politique" to lay the ground for his claim that Societal Constitutionalization should focus on the "internal politics of social subsystems." 50 This turn to a double concept of politics and the political, however, is bound to entrench a rather artificial separation between institutionalized politics within the nation-state and political action beyond the nation-state.

Admittedly, the idea behind the distinction between "la politique" and "le politique" is appealing, as it seems to be well founded in systems theory. Luhmann acknowledges that the functional systems of society have inherent potentials for self-reflection and for reflecting on their identity in relation to other functional systems of society. ${ }^{51}$ It is these potentials for self-reflection that Teubner addresses with his concept of le politique. With regard to the economic system, for example, he argues that central banks can be seen as an institutionalized form of systemic self-reflection, as allowing a self-limitation of the money medium without intervention from the political system (i.e., la politique).$^{52}$

48. See Joerges, supra note 31.

49. This fixation was certainly not present in early socialist strands of the theory. See NAPHTALI, supra note 5, at 30-31 (describing the role of the state and, more generally, the 'polity' for realizing Economic Democracy).

50. TEUBNER, supra note 3 , at 114-23.

51. NikLas LuHMANN, SOZLALE SySTEME: GRUNDRIB EINER allgemeinen Theorie [SOCIAL SYSTEMS: OUTLINE OF A GENERAL THEORY] 234 (1984) (Ger.).

52. TEUBNER, supra note 3 , at 96-102. 
The example of central banks, however, shows that Teubner's approach does not sufficiently reflect on the ambiguous role of such institutions within both the economic and the political system: central banks' decisions on monetary policy are neither reducible to the medium of the economic system (money) nor to the medium of the political system (power). Rather, they take on a mediating role between both functional systems without being wholly integrated into either of them. This is why Luhmann expressly names central banks as an example for the structural coupling between economy and politics. ${ }^{53}$ And this is also why Teubner himself, tellingly, formulates his claims for "full money reform" as claims for a political reform of the Statute of the European Central Bank. ${ }^{54}$ The idea of an internal system reflection of le politique, therefore, does not seem to sufficiently account for the enduring importance of the political system in late capitalist society.

What Teubner's approach rightly stresses on the basis of Luhmannian systems theory is the idea that political communication is not necessarily limited to the institutions of the nation-state..$^{55}$ Yet this does not follow from system-specific modes of reflection, but from the nature of political communication itself. For Luhmann, political communication is communication that is articulated in the power medium. ${ }^{56}$ As such, it is pervasive in all functional systems of society. The central issue for systems theory as a theory of functional differentiation, then, is to define the conditions under which such communication can develop into a functional system of its own. ${ }^{57}$ Historically, these conditions have been fulfilled with the emergence of the modern nation-state, which provided for a separation of political offices from personal and familial relations and, at the same time, instituted a procedural framework for the filling of such positions, namely elections. ${ }^{58}$ Under these conditions, political communication became self-referential: the relevance of social issues within the political and electoral process became itself a political question, a question determined in political procedures. ${ }^{59}$

This Luhmannian model of politics as a self-referential system can, by way of generalization and respecification, be transposed to the transnational arena. Indeed, it provides an excellent conceptual

53. Niklas Luhmann, Das Recht der Gesellschaft [LaW as a Soclal System] 451

(1993) (Ger.); see also LUHMANN, supra note 24 , at 345.

54. TEUBnER, supra note 3, at 100-01.

55. Id. at 114-23.

56. Niklas Luhmann, Die Politik der Gesellaschaft [The Politics of Civil Society] 45,75 (2002) (Ger.).

57. Id. at 69,76 .

58. Id at 91-94.

59. Id. at 86 . 
framework for analyzing novel constellations of economy, politics, and law beyond the nation-state. My contribution therefore relies on a very basic model of systemic differentiation without employing the Teubnerian distinction between la politique and le politique. It does, however, agree with what I suppose to be the central tenets of the theory of Societal Constitutionalism, that is, (1) that the approaches of Economic Constitutionalism and Economic Democracy are compatible; and (2) that those approaches must be generalized and respecified for an analysis of constitutionalization processes beyond the nation-state. The basic features of an economic constitution allowing for processes of political reflection will thus be both defined in an abstract manner and illustrated by concrete phenomena in social practice.

\section{Project and PracticE: Transnational Societal CONSTITUTIONALISM AND THE ECONOMY}

This generalization and respecification will be undertaken with a view to the example of transnational standard-setting in corporate financial reporting. My analysis here proceeds in two steps. In the first step, I will show how the field of corporate financial reporting is shaped by transnational rules of law (Part A). In the second step, I will analyze both the constitutive and the limitative function that (secondary) legal rules play in this field, thus enabling a process of constitutionalization in the strict sense (Part B). This constitutionalization process has two different aspects: a hierarchization of norms on the one hand (Part B.1), and the emergence of a structural coupling between economy, law, politics, and science, on the other (Part B.2).

\section{A. International Financial Reporting Standards as Transnational Law}

Rules on financial reporting play a paramount role in market economies dominated by corporations. Such rules are almost as old as capitalism itself: As early as 1673, France first established a duty for enterprises to publish annual reports. ${ }^{60}$ Initially, reporting requirements had the primary purpose of enabling state oversight of corporate finance, for example, to avoid bankruptcies and protect creditors. ${ }^{61} \mathrm{~A}$ similar approach to regulating financial reporting was soon taken by other continental European nation-states. In Great

60. Stanley E. Howard, Public Rules for Private Accounting in France, 1673 and 1807, 57 The ACCOUNTING ReV. 91 (1982).

61. See CHRISTOPH WATRIN, Einführung in die Rechnungslegung nach IFRS [Introduction to Accounting According to IFRS], in MÜNCHENER KOMMENTAR ZUM BILANZRECHT [MUNICH COMMENTARY ON ACCOUNTING LAW] para. 1, (Joachim Hennrichs ed. 2008) (Ger.). 
Britain and the United States, in contrast, where economies were traditionally more oriented toward equity investors and capital markets, ${ }^{62}$ financial reporting was considered a matter of private interest alone. ${ }^{63}$ Corporations were thought to have sufficient incentives to disclose their financial situation because they had to attract investors on the capital markets. Notwithstanding stronger regulatory interventions after the 1929 economic crisis and the ensuing establishment of the Securities and Exchange Commission, standard-setting in financial reporting was therefore largely left to private bodies. ${ }^{64}$

Only at the end of the twentieth century, with economic globalization and an ever-stronger integration of global capital markets, did the need arise for a worldwide harmonization of financial reporting standards. 65 While continental European harmonization attempts remained limited to the EU context, the first steps toward the elaboration of global financial reporting standards were taken with the establishment of the International Accounting Standards Committee (IASC) in 1973, a private standard-setting organization domiciled in London. ${ }^{66}$ Early codifications of financial reporting standards elaborated by the IASC, the International Accounting Standards (IAS), remained of rather marginal relevance until 2000, when the International Organization of Securities Commissions (IOSCO) recommended IAS standards as a requirement for domestic stock market listings. ${ }^{67}$ In the same year, the European Commission made financial reporting according to the IAS compulsory for large European groups of companies. ${ }^{68}$ Now the IAS-succeeded by the International Financial Reporting Standards (IFRS)-are on the way to becoming the globally accepted standard in corporate financial reporting. ${ }^{69}$

After the first stages of the current financial crisis, financial reporting standards set by the International Accounting Standards Board (IASB), the successor organization of the IASC, have been heavily

62. See Peter A. Hall \& David Soskice, An Introduction to Varieties of Capitalism, in VARIETIES OF CAPITALISM: THE INSTTTUTIONAL FOUNDATIONS OF COMPARATIVE AdVANTAGE (Peter A. Hall \& David Soskice eds., 2001).

63. See Walter Mattli \& Tim Büthe, Global Private Governance: Lessons from a National Model of Setting Standards in Accounting, 68 LAW \& CONTEMP. ProBs. 225, 237 (2005).

64. Watrin, supra note 61 , at para. 2 .

65. Mattli \& Büthe, supra note 63 , at 228 .

66. Watrin, supra note 61 , at paras. 3-7.

67. Cf. Mattli \& Büthe, supra note 63 , at 252 .

68. Regulation (EC) No.1606/2002 of the European Parliament and of the Council of 19 July 2002 on the Application of International Accounting Standards.

69. Watrin, supra note 61 , at 10. 
criticized, especially in continental Europe. ${ }^{70}$ The main thrust of the critique was directed at the IAS and IFRS principle of "fair value" accounting. ${ }^{71}$ The "fair value" principle demands that a corporation's assets be reflected in financial reports according to their current market price. The principle, thus, stands in stark contrast to the "principle of conservatism" traditionally embodied, for example, by German commercial law. Its critics argue that the "fair value" principle has, by its procyclical effects, accelerated the financial meltdown of the first years of the crisis. ${ }^{72}$

But what is, after all, the status of such principles? How can the recommendations of a private standard-setting body have potentially harmful effects on the global economy? These questions can be answered by reconstructing the IASB standard-setting process as a transnational legal process, enabling a self-regulation of the economic sphere backed by procedural rules of law. ${ }^{73}$ An in-depth discussion of the legal nature of the IAS and IFRS standards is not even necessary for this purpose. ${ }^{74}$ Even from the perspective of state-centered legal positivism the standards must be considered legal norms, as they are expressly granted this status by EU legislation. ${ }^{75}$ Therefore, domestic courts can apply and interpret the standards. The IAS and IFRS standards themselves apparently reflect their nature as legal norms in their internal structure: they define applicability and scope, lay down well-defined duties and obligations (such as "an entity shall prepare"), include list of defined terms, and conclude with an "effective date."76

The genesis of the standards is typical for transnational legal processes in three different respects. ${ }^{77}$ First, they erode the boundary between public and private modes of governance: public regulatory authorities delegate quasi-legislative powers to a private standard-setting body, and the rules made by this private body are

70. For an overview, see e.g. Christian Laux \& Christian Leuz, The Crisis of FairValue Accounting: Making Sense of the Recent Debate, 34 ACCOUNTING, ORGANIZATION AND SOCIETY 826 (2009).

71. IAS 32.11 , IAS 39.9 .

72. Cf. Laux \& Leuz, supra note 70 , at 826 .

73. Mattli \& Büthe, supra note 63, at 261-62.

74. On the thinning boundary between legal and social norms in transnational governance see e.g. Gralf-Peter Calliess \& Moritz Renner, Between Law and Social Norms: The Evolution of Global Governance, 22 RATIO JURIS 260 (2009).

75. On different techniques of integrating transnational norms into domestic legal systems see Ralf Michaels, The Re-State-ment of Non-State Law, 51 WAYNE L. REv. 1209 (2005).

76. See e.g. IAS 1 on Presentation of Financial Statements, especially IAS 1.7-8A, 1.27, 1.139-1.139L.

77. On the defining aspects of transnational legal processes see MORITZ RENNER, ZWINGENDES TRANSNATIONALES RECHT 215-28 (2011) (Ger.). 
given the force of law through public legislation. ${ }^{78}$ Second, they-at the same time-bridge the gap between domestic and international regulation. The international standards set by the IASB are expressly incorporated into domestic law. ${ }^{79}$ Third, the IASB standard-setting process combines normative universality with specificity of scope: the standards are applicable worldwide, but narrowly restricted to a specific issue area. ${ }^{80}$ All three features combined provide for a most efficacious mode of transnational governance that avoids the shortcomings of the domestic lawmaking process.

\section{B. The Constitutionalization of International Financial Reporting}

The generation of transnational legal norms in the field of financial reporting is both enabled and limited by an emerging layer of constitutional rules that assume a higher normative rank than the IAS and IFRS standards and, at the same time, selectively open the standard-setting process for inputs from political and scientific discourse.

\section{Normative Hierarchies}

That the IASB standard-setting process is both enabled and limited by higher ranking norms is most visibly expressed by the fact that the IFRS Foundation, which oversees the IASB, established its own "Constitution" in 2000. The IFRS Foundation Constitution (FC) ${ }^{81}$ lays down the basic rules of governance of the IFRS Foundation ${ }^{82}$ and defines its numerous bodies: the Trustees, ${ }^{83}$ the Monitoring Board ${ }^{84}$ the IASB, ${ }^{85}$ the Interpretations Committee, ${ }^{86}$ and the Advisory Council. ${ }^{87}$ Each body is vested with a specific set of competences; the interaction of the bodies is regulated in a highly detailed manner. According to the Constitution, the Monitoring Board of the IFRS Foundation,

78. See Mattli \& Büthe, supra note 63 , at 255.

79. See Regulation (EC) No.1606/2002 of the European Parliament and of the Council of 19 July 2002 on the Application of International Accounting Standards.

80. See Mattli \& Büthe, supra note 63, at 235-37.

81. Constitution, IFRS FOUNDATION (Jan. 2013), available at http://www.ifrs.org/Theorganisation/Governance-and-accountability/Constitution/Documents/IFRS-Foundation-

Constitution-January-2013.pdf

82. Id. at Sec. 3

83. Id. at Sec. 4-17.

84. Id. at Sec. 18-23.

85. Id. at Sec. 24-38.

86. Id. at Sec. $39-43$.

87. Id. at Sec. 44-46. 
representing public capital market authorities, appoints the Trustees, twenty-two individuals from all regions of the world representing "an appropriate balance of professional backgrounds." 88 These trustees in turn appoint both the Advisory Council as well as the standard-setting bodies in the strict sense, the IASB and the Interpretations Committee. The IASB as the central standard-setting body comprises fourteen members whose main qualifications "shall be professional competence and practical expertise." 89

\section{Figure 1: Structure of IFRS Foundation}

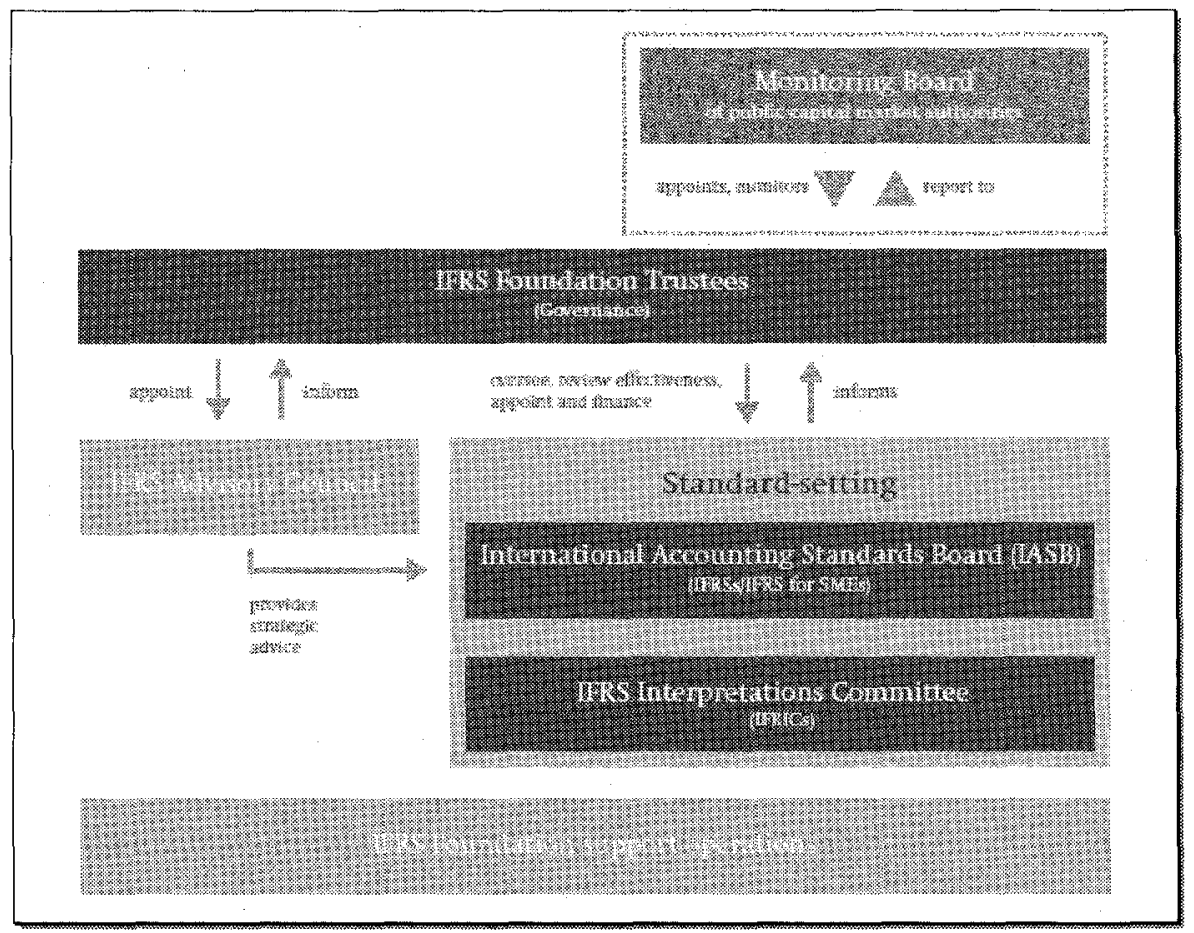

Source: How We Are Structured, IFRS FOUNDATION, http:/www.ifrs.org/theorganisation/Pages/How-we-are-structured.aspx (last visited Aug. 1, 2013).

The IFRS Foundation Constitution thus establishes secondary rules in a manner highly similar to the organizational provisions of nation-state constitutions:

88. Id. at Sec. 6-7.

89. Id. at Sec. 25. 
[T] hey may all be said to be on a different level from the primary rules, for they are all about such rules; in the sense that while primary rules are concerned with the actions that individuals must or must not do, these secondary rules are all concerned with the primary rules themselves. They specify the ways in which the primary rules may be conclusively ascertained, introduced, eliminated, varied, and the fact of their violation conclusively determined.90

In relation to the primary norms generated by the IASB (the IAS and IFRS standards), the higher normative rank of the Constitution is ensured by the strict requirements for constitutional revisions and amendments. In a paradoxical move, also common in nation-state constitutional documents, the IFRS Constitution defines these requirements itself. In contrast to other decisions made by the Trustees, for which a simple majority under the "one man, one vote" principle is sufficient, amendments to the Constitution require a seventy-five percent majority of the votes. At this point, it becomes apparent that the IFRS Constitution is not merely an organizational constitution but the constitution of a legal regime: It not only institutes and circumscribes the powers of organizational actors but also structures a process of rulemaking. With the possibility of constitutional amendments, this rulemaking process becomes self-referential; the validity of the rulemaking process is itself made dependent on a rulemaking process. ${ }^{91}$

Beyond the Constitution, another layer of secondary rules is generated by the "Interpretations" issued by the Interpretations Committee. The Interpretations Committee, consisting of "a group representing, within that group, the best available combination of technical expertise and diversity of international business and market experience in the practical application of the IFRSs and analysis of financial statements prepared in accordance with IFRSs." 92 The Committee, after a public consultation process, publishes Interpretations regarding the application of IFRS standards. ${ }^{93}$ The Interpretations are authoritative and have the same normative status as the standards themselves. ${ }^{94}$ The Interpretations Committee practically assumes the role of a Supreme Court in transnational

90. HERBERT L.A. HART, THE CONCEPT OF LAW 94 (2nd ed. 1961).

91. Watrin, supra note 61 , at paras. 3-7.

92. Constitution, supra note 81 , at Sec. 39 .

93. Id. at Sec. 43.

94. IAS 1.11 (c). See LAS 1-Presentation of Financial Statements, DELOITTE, available at http://www.iasplus.com/en/standards/ias/ias1 (last visited Oct. 2, 2013). 
financial reporting. It institutes a (nonadversarial) procedure for conclusively resolving conflicts of interpretation and generating interpretive rules that effectively supersede the primary norms of the standards.

\section{Structural Couplings: Economy, Law, Politics, and Science}

The emergence of normative hierarchies in transnational financial reporting thus establishes the prerequisites for a lawmaking process marked by the close interaction of economic and legal rationality. The IFRS Foundation Constitution sets the framework for self-regulation of economic actors through a transnational governance process. It fulfills the central function of an economic constitution both institutionally supporting and limiting market processes in the economic sphere by allowing for an elaboration of financial reporting standards, which in turn enable economic actors to make informed investment decisions. At the same time, through the above-mentioned appointment procedures it encompasses safeguards that ensure that the standard-setting process is not distorted by economically powerful actors, corruption, or a simple lack of information.

But how does this economic constitution account for the role of politics? Does it fulfill the hopes of Societal Constitutionalism, opening up perspectives for a reconciliation of Economic Constitutionalism and Economic Democracy, a transnational politicization of the economy in view of the systemic limitations of both economic and political rationality?

To answer these questions, it is necessary, once again, to generalize and respecify one of the central features of modern nation-state constitutionalism, that is, the close trilateral interaction of the functional systems of society not only with law, but also with politics (the "magic triangle"). ${ }^{95}$ Teubner's theory of Societal Constitutionalism holds that, on the transnational level, the structural coupling ${ }^{96}$ between law and other functional systems can be supplemented by an internal politicization of the functional system concerned-in our case the economy..$^{97}$ As sketched above, ${ }^{98}$ a consistent application of the concepts of systems theory should instead conceive of politics as a functionally differentiated system on its own. The constitutionalization of transnational governance processes in economic law can then be

95. TEUBNER, supra note 3 , at 7 .

96. On the concept of structural couplings see NIKLAS LUHMANN, LAW AS A SOCIAL SYSTEM 381-422 (2004).

97. See TEUBNER, supra note 3 , at 119-23.

98. See Section IV, supra. 
modeled as a structural coupling between three functional systems: economy, law, and politics. ${ }^{99}$ This trilateral model of economic constitutions developed in the nation-state context is not only sufficiently general to be applied to the transnational arena, it has the additional advantage of acknowledging the fundamental incommensurability of economic, political, and legal rationality.

Whether and how the global economy is not only coupled to legal but also to political processes in the transnational arena can only be analyzed with a view to specific institutions and procedures. In the case of transnational standard setting in financial reporting, this demands a closer look at the standard-setting process itself. The basic rules of this process are, again, to be found in the IFRS Foundation Constitution. 100 The Constitution foresees that the IASB as the central standard-setting body shall "publish an exposure draft on all projects and normally publish a discussion document for public comment on major projects in accordance with procedures approved by the Trustees." 101 It is only after a public consultation process, which is further specified in the so-called Due Process Handbook (DPH), that standards are finalized and pipelined to the jurisdictional adoption process. ${ }^{102}$

The DPH outlines six phases of the standard-setting process. In phase one ("setting the agenda"), the IASB identifies potential fields of regulation, potentially by conducting or supervising appropriate research projects. ${ }^{103}$ In phase two ("project planning"), a project team is set up and potential areas of cooperations with other standard setters are identified. In phase three ("discussion paper"), a paper is elaborated and published that explains the issues addressed by the future regulation and lists possible approaches to the issue, inviting comments. ${ }^{104}$ In phase four ("exposure draft"), a more detailed document is elaborated "on the basis of staff research and recommendations." 105 This "exposure draft" is the basis for the ensuing public consultations, which are conducted mainly through the solicitation of comments for a period of 120 days after publication of the draft. ${ }^{106}$ In addition to inviting comment letters, the IASB "often considers holding public

99. Of course, there is no single trilateral coupling mechanism, as Teubner understands me to argue (TEUBNER, supra note 3 , at 117), but two distinct structural economy-law and law-politics. See RENNER, supra note 77, at 39-40.

100. Constitution, supra note 81.

101. Sec. 37 (b).

102. Constitution, supra note 81.

103. Due Process Handbook, Sec. 25-26, IFRS Founda'TION (Feb. 2013), available at http://www.ifrs.org/DPOC/Documents/2013/Due-Process-Handbook-February-2013.pdf.

104. Id. at Sec. 31.

105. Id. at Sec. 39.

106. Id. at Sec. 41-44, 99-100. 
meetings with interested organizations to listen to and exchange views on specific topics"; 107 it may also "arrange public round-table meetings to discuss issues with interested parties." 108 In stage five of the process ("development and publication"), the IASB then evaluates the results of public consultation and, potentially after going through a second round of consultations, finalizes and publishes the new standard. After the standard is issued, it is implemented in domestic jurisdictions during phase six ("procedures after an IFRS is issued"), and the IASB carries out a post-implementation review. ${ }^{109}$

Figure 2: How IFRS Develops Standards

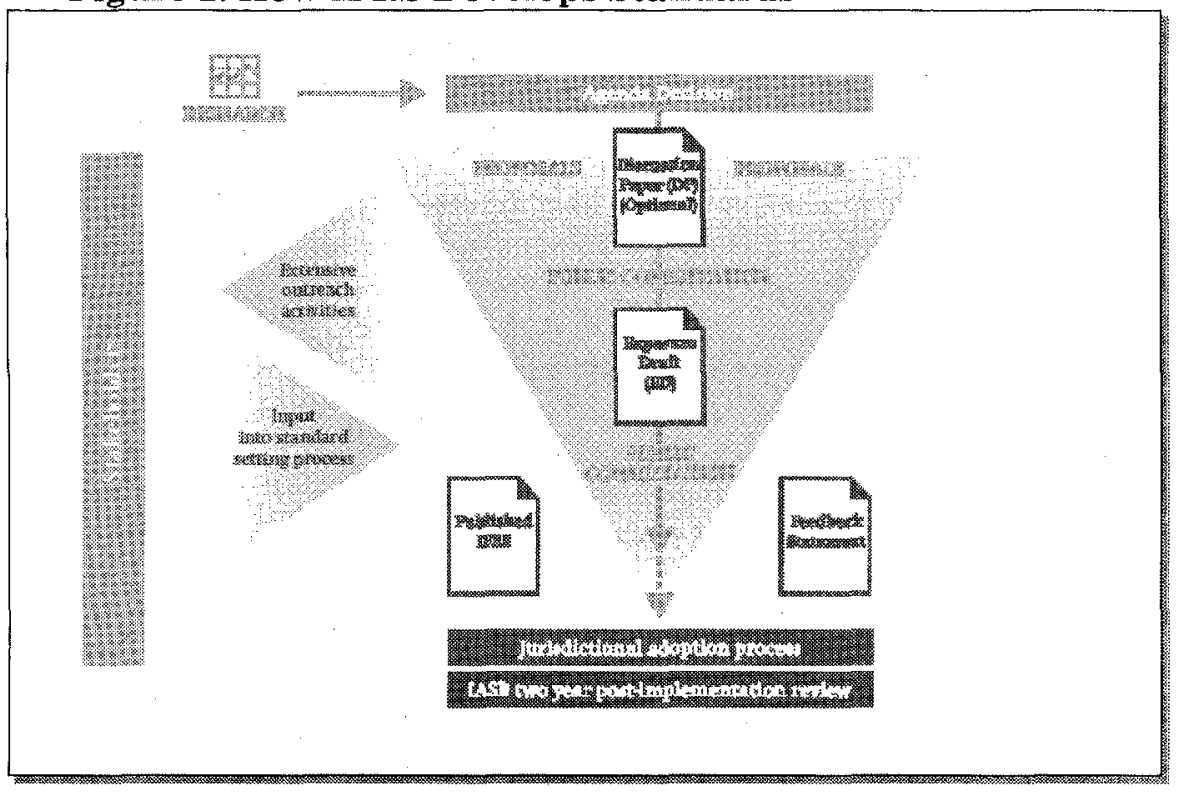

Source: Who We Are and What We Do, IFRS FOUNDATION, at 3, available at http://www.ifrs.org/The-organisation/Documents/Who-We-Are-English-2013.pdf (last visited Sept. 1, 2013).

Thus, the IASB standard-setting procedure at various stages allows for a reflection of political rationality, or more precisely, exposes structural couplings of the transnational legal process to an emerging political system beyond the nation-state. The structural coupling of economy and law, which is enabled by the IFRS Foundation Constitution, is thus transformed into a trilateral constellation of

107. Id. at Sec. 105 .

108. Id. at Sec. 107.

109. Id. at Sec. 53. 
economy, law, and politics. This is most visible in the public consultation process as described by the Due Process Handbook. A systemic view, which focuses on modes of communication rather than solely on the participating actors, ${ }^{110}$ shows that the consultations are not dominated by the binary code of the economic system ("payment or non-payment"), ${ }^{111}$ but increasingly subjected to the logics of the political system ("power or powerlessness"). 112

In a typical consultation procedure, there are comment letters from several hundred stakeholders. ${ }^{113}$ The stakeholders include large corporations, both private and public (such as Royal Dutch Shell, Unilever, and the Bank of China), business associations (such as the Institute of Chartered Accountants of India), nongovernmental organizations in the broadest sense (such as the International Corporate Governance Network), public authorities (such as the European Central Bank, the World Bank, and the Autorité des marchés financiers), and academics. The stakeholders present themselves as representatives ${ }^{114}$ of certain groups and interests. On this basis, they engage in a debate that is in part highly technical, but at the same time makes reference to more general aims. Although there seems to be hardly any guidance for the IASB in evaluating and weighing stakeholders, the public consultation process can thus be considered a reflection of an emerging political discourse on the global stage, which not only comes very close to Berle's model of public consensus but also fulfills the basic conditions for a functional differentiation of political communication in the Luhmannian sense.

For Luhmann, there is a functional differentiation of political communication as soon as political discourse emancipates itself from its social context by orienting discussions along the lines of political allegiances (e.g., the "left or right scheme") rather than toward the solution of individual social conflicts. ${ }^{115}$ Accordingly, "political conflicts are conflicts which only take place within the operationally closed

110. See generally LUHMANN, supra note 51.

111. LUHMANN, supra note 24 , at 69.

112. See generally LUHMANN, supra note 56 .

113. See e.g. IFRS 9: Financial Instruments (Replacement of LAS 39), IFRS FOUNDATION, available at http://www.ifrs.org/current-projects/iasb-projects/financialinstruments-a-replacement-of-ias-39-financial-instruments-recognitio/Pages/financialinstruments-replacement-of-ias-39.aspx (last visited Oct. 2, 2013).

114. On the representative function of the 'stakeholder' concept in the transnational constellation see Poul Kjaer, The Concept of the Political in the Concept of Transnational Constitutionalism: A Sociological Perspective, in AFTER GLOALIZATION-NEW PATTERnS OF CONFliCt AND THEIR SociologiCal AND Legal RECONSTRUCTION 285-321 (Christian Joerges \& Tommi Ralli eds., 2011).

115. LUHMANN, supra note 56, at 95. 
political system." 116 And, paradoxically, this is made possible by the very idea that actors in political discourse act as representatives of certain interests or social groups, as it can be observed in the IASB standard-setting procedure. The very idea of representation is based on a problem of difference:117 The representative and the represented are never identical; rather, the object of representation ("the people" or "stakeholders") is only created in the process of representation ("government" and "governance"). ${ }^{118}$

As soon as this difference is established, references to the "common good," as they are increasingly used in IASB consultations, must be understood as referring to a "contingency formula." 119 The concept of the "common good" has no fixed meaning and no social substrate. Rather, it allows for a political debate on the question of which issues can be considered as political issues in the first place. ${ }^{120}$ It is at this point that political discourse becomes self-referential and thus functionally differentiated. Specifically, which private interests should be reflected in public rulemaking can now be discussed politically. ${ }^{121}$ If, for example, the Anglo-American finance industry wants the principle of "fair value" accounting to be implemented in IFRS standards, this particular interest must be voiced in a manner that makes it acceptable as promoting not merely vested interests, but a common good for all parties concerned: more transparency, enhanced uniformity, and simplicity of rules, for example. The IASB standard-setting procedure, by way of its consultation procedure, not only reflects but also triggers such processes of political debate. The transnational lawmaking process between economy and law is thus closely coupled to an emergent political discourse.

Less visibly than in public consultations, structural couplings between law and politics can also be found at the very beginning and at the very end of the standard-setting process. First, it is important to keep in mind that the IFRS Foundation Trustees are appointed and monitored by public capital market authorities. Second, it must be noted that the adoption and implementation of IAS and IFRS standards is a matter of domestic jurisdictions. ${ }^{122}$ At both points of the process, nation-state politics, and thus parliamentary democracy, still play a

\footnotetext{
116. Id. at. 96 .

117. See generally MicheL FouCAULT, LES MOTS ET LES CHOSES (1966) (Fr.).

118. See LUHMANN, supra note 56, at 116.

119. Id. at. 120 .

120. Id. at. 122 .

121. Id. at. 122 .

122. For a critical account on this mechanism see Christian Kirchner \& Matthias Schmidt, Private Law-Making: IFRS-Problems of Hybrid Standard Setting, in INTERNATIONAL STANDARDS AND THE LAW 67-82 (Peter Nobel ed., 2005).
} 
role. Here, we can see that the trilateral constellation of economy, law, and politics in the transnational arena is-as compared to the nation-state model-complicated by an internal differentiation of the global political system. ${ }^{123}$ While economic communication is integrated into a global system that has no difficulties in crossing the borders of the nation-state and is increasingly supplemented by transnational legal structures, the global political system is still fragmented into a rudimentary form of genuinely global political discourse, on the one hand, and politics within-and among-the nation-states on the other. Both formations are reflected in the constitutionalization of transnational economic governance.

But the constitutionalization of transnational governance in financial reporting is not restricted to the trilateral constellation of economy, law, and politics. It is striking how the IASB standard-setting process, at various stages, also incorporates scientific knowledge and research. Here, a development which can already be observed on the nation-state level is continued and intensified. The coupling of economy, law, and politics is increasingly stabilized by a further structural coupling of law and science: lawmaking processes integrate and reflect expert knowledge, thus mediating between normative and cognitive expectation structures to adapt to complex regulatory environments. ${ }^{124}$

\section{PERSPECTIVES}

A close analysis of the IASB standard-setting process thus demonstrates how transnational governance regimes materialize at the boundary of economy and law, and how such transnational governance regimes can be constitutionalized. Two features are defining for this constitutionalization: the emergence of a hierarchy of primary and secondary norms and the structural coupling of the transnational law-making process to the political system. As the global political system is marked by an internal multilevel structure, different levels and different forms of political discourse are therein reflected.

But what does the analysis of this example for transnational constitutionalization contribute to the ongoing debate between Economic Democracy and Economic Constitutionalism? First, it should teach proponents of both approaches modesty and realism-the same modesty and realism that is shown by the early proponents of both approaches, such as Naphtali and Böhm. On the transnational level, the

123. LUHMANN, supra note 56 , at 222.

124. Moritz Renner, Death By Complexity. The Financial Crisis and the Crisis of Law in World Society, in THE FINANCIAL CRISIS IN CONSTITUTIONAL PERSPECTIVE: THE DARK SIDE of FUNCTIONAL DiFfERENTIATION 93-111 (Poul Kjaer, et al. eds., 2011). 
conflict between economic and political rationality persists-even if in a different form. ${ }^{125}$ Novel models of public consultation and participation do not allow for dissolution of the incommensurable rationalities into deliberative universality. Neither do they institute a purified form of the ordoliberal economic constitution. Rather, they combine elements of both models. The example of transnational governance in financial reporting clearly exhibits traits of an economic constitution in the ordoliberal sense (containment of economic and political power by rules of law). At the same time, it partially fulfills the normative hopes of Economic Democracy by translating political decision-making structures into the economic rules of the game (coupling of economic and political discourse).

Thus, the paradoxical agenda of Societal Constitutionalism finds a concrete institutional form in transnational economic governance, allowing for a controlled interaction of economy and politics through legal means. However, the transnational constellation of economy, law, and politics in many ways mirrors the institutionalized legal and political economy of the nation-states. As transnational economic governance goes through ever more intense processes of juridification and constitutionalization, comparable to those of the nation-states in the nineteenth century, it is also bound to reenact the nation-state's crises of power and legitimacy. ${ }^{126}$ The open question is no longer whether the global economy can be constitutionalized through a nexus of law and politics, but which form of political discourse takes on in the transnational constellation. Here, as the example of IASB standard-setting demonstrates, references to public consensus oscillate between appeals to deliberative democracy and invocations of expertise or vested interests. But one can observe that the consultations within the IASB procedures are by now becoming politicized in a very fundamental sense: they increasingly refer to contingent conceptions of the common good--and thus allow for genuinely political contestations of the concept itself.

125. See Karl Polanyt, Globalisation and the Potential of LaW in Transnational MARKETS (Christian Joerges \& Josef Falke eds., 2011).

126. See generally JÜRGEN HABERMAS, LEgITLMATIONSPROBLEME IM SPÄTKAPITALISMUS (1973) (Ger.). 